\title{
Onkoloji Hemşirelerinin Tükenmişlik ve İş Doyumu Düzeyleri: Adana Örneği*
}

\author{
Level of Burns and Job Satisfaction of Oncology Nurses: Adana Case \\ Gülşah Kumaşi, Sibel Öner Yalçınii, Gürsel Öztunçii
}

i Dr. Öğr. Üyesi, Çukurova Üniversitesi Sağlık Bilimleri Fakültesi Hemşirelik Bölümü, https://orcid.org/0000-0002-5102-2643

iiDr. Öğr. Üyesi, Pamukkale Üniversitesi Tıp Fakültesi Tıp Tarihi ve Etik Anabilim Dalı, https://orcid.org/0000-0002-6122-7087

iiiProf.Dr., Girne Üniversitesi Sağlık Bilimleri Fakültesi Hemşirelik Bölümü, https://orcid.org/0000-0002-7997-6377

öz

Onkoloji birimlerinde çalışan hemşireler sıklıkla ağır sağlık problemleri olan hastalarla çalışmak zorundadırlar. Kanser tanısı konulmasından hastanın kaybedilmesine kadar olan süreç sadece hasta ve ailesi için değil bakım veren hemşireler için de çeşitli zorluklar içermektedir. Hastaların ağır yan etkileri olan tedavilerini yönetme, hastaların tedaviye uyum sorunları, hastaların ağrı ve acı çekmesine şahitlik etme, ekip çatışmaları, terminal dönem hastalarının bakımı ve kaybedilmesi ile ilgili yaşanan stresli durumlar bu zorluklardan bazılarıdır. Araştırmamız onkoloji hemşirelerinin iş doyumu ve tükenmişlik düzeylerini belirlemek amacı ile tanımlayıcı olarak yapılmıştır.

Araştırmamız, Adana il merkezinde biri devlet diğeri vakıf olmak üzere iki üniversite hastanesi ile bir devlet hastanesinin onkoloji ve hematoloji birimlerinde görev yapan 72 hemşirenin katılımıyla yapıımıştır. Araştırmamızda Maslach Tükenmişlik Ölçeği ve Minesota İ̧̧ Doyum Ölçeği kullanıımıştır.

Araştırma sonuçlarına göre hemşirelerin yaş ortalaması $31.2 \pm 8.4, \% 56.9$ 'u evli, \%48.6'sı lisans mezunu, \%16.7'si ise onkoloji

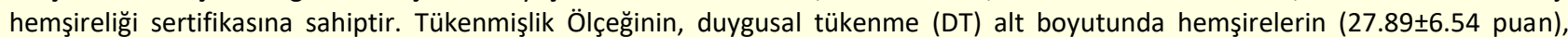
duyarsızlaşma (D) alt boyutundan (12.53 \pm 4.71 puan) yüksek düzey tükenme yaşadıkları, kişisel başarı (KB) alt boyutunda ise düşük düzey tükenmişlik yaşadıkları belirlenmiştir. İ̧̧ doyum ölçeğinin içsel doyum puan ortalaması $36.19 \pm 9.88$, dışsal doyum puan ortalaması ise $21.64 \pm 6.26^{\prime}$ dır.

Sonuç olarak hemşirelerin yüksek düzeyde tükenmişlik yaşadıkları, ancak başkalarına faydalı olduklarını düşündükleri için kişisel başarı duygusu ve orta düzeyde iş tatmini yaşadıkları söylenebilir.

Anahtar Kelimeler: Hemşire, Onkolojik Hasta, Tükenmişlik Sendromu, İş Doyumu

ABSTRACT

Nurses working in oncology units often have to work with patients with severe health problems. From the diagnosis of cancer to the loss of the patient, the process includes various difficulties not only for the patient and his / her family but also for the nursing nurses. These challenges include making critical decisions for the patient, managing treatments with serious side effects, patients' anger and non-compliance problems, monitoring patients suffering from pain and suffering, intra-team conflicts, and the care and death of terminal-term patients. Our study was carried out as descriptive to determine job satisfaction and burnout levels of oncology nurses.

Our study was carried out with the participation of 72 nurses who work in oncology and hematology departments of two university hospitals and one state hospital in Adana city center. In our study, Maslach Burnout Inventory and Business Satisfaction Scale were used.

According to the results of the study, the mean age of nurses was $31.2 \pm 8.4,56.9 \%$ were married, $48.6 \%$ were bachelor's degree, and $16.7 \%$ were oncology nursing. It was determined that Burnout Scale experienced high level of depletion in nurses (27.89 \pm 6.54 points), desensitization (D) sub-dimension (12.53 \pm 4.71 points) in the subscale of emotional exhaustion (PD), and low level burnout in personal achievement (BP) sub-dimension. The mean satisfaction score of the job satisfaction scale was $36.19 \pm 9.88$, and the mean score of external satisfaction was $21.64 \pm 6.26$.

As a result, it can be said that nurses experience high levels of burnout, but because they think they are beneficial to others, they experience personal sense of accomplishment and moderate job satisfaction.

Keywords: Nurse, Oncological Patient, Burnout Syndrome, Job Satisfaction

*Lokman Hekim Dergisi, 2019; 9 (2): 256-265

DOI: $10.31020 /$ mutftd.550272

e-ISSN: 1309-8004

Geliş Tarihi - Received: 6 Nisan 2019; Kabul Tarihi - Accepted: 10 Mayıs 2019

iletişim - Correspondence Author: Gülşah Kumaş<gulsahkumas@gmail.com> 


\section{Giriş}

Günümüzde erken tanı ve tedavi yöntemlerinde kaydedilen gelişmeler ile kanser tanısı alan bireyler daha uzun süre yaşamakta dolayısıyla uzun süreli hemşirelik bakımına gereksinim duymaktadırlar. ${ }^{1,2}$ Hemşirelerin onkoloji alanındaki rolleri erken teşhis ve önleyici girişimlerden, hastaların terminal dönem bakımına kadar uzanan geniş bir yelpazeye sahiptir. Onkoloji birimlerinde çalışan hemşirelerin, kemoterapi ve radyoterapi sürecinde hastanın değerlendirilmesi ve bakımı, semptom kontrolü, hasta ve ailesinin eğitimi, bakımın koordinasyonu gibi rol ve sorumlulukları vardır. ${ }^{3}$ Onkoloji hastalarının tedavi ve bakım süreçleri karmaşık duygusal, fiziksel, sosyal ve psikolojik zorluklar içermektedir. ${ }^{4}$ Callaghan ve Lee'nin onkoloji hemşirelerinin yaşadığı zorluklara ilişkin yaptıkları çalışmada bu zorluklar, hasta için kritik kararlar verme, tedavilerin yan etkileri yönetme, hastaların tedaviye uyumu ile ilgili sorunlar, hastaların yaşadığı ağı ve acıya şahitlik etme, ruhsal problemler, ekip içi çatışmalar, terminal dönem hastalarının bakımı ve ölümü ile ilgili yaşanan stresli durumlar olarak sıralanmıştır., Ülkemizde, konu ile ilgili yapılan bazı çalışmaların sonuçlarına göre kanser hastalarının tedavisinde kullanılan antineoplastik ilaçların hazırlanması, uygulanması ve sonrasında yapılan bakım girişimleri hemşire ve diğer sağlık çalışanlarını olumsuz olarak etkilemektedir. ${ }^{7,8}$ Bunların yanında uygun olmayan çalışma ortamı ve çalışma saatleri, mesleği istemeyerek seçme ve sürdürme, malzeme ve personel yetersizliği, hasta sayısının artmasına bağlı gelişen iş yoğunluğu, antineoplastik ilaçların hazırlanması sırasında koruyucu önlemlerin yetersiz kalması gibi olumsuz koşulların da onkoloji hemşirelerinin çalışmaları sırasında zorluk yaşamalarına neden olduğu bildirilmektedir. ${ }^{9,10}$

Diğer ülkelerde olduğu gibi Türkiye'de de kanser vakaları artış göstermekte dolayısıyla onkoloji hemşirelerinin iş yükü ve iş stresi artmaktadır. Uzun süren iş stresi tükenmişlik ve iş doyumunda azalma için zemin hazırlamaktadır. Sağlık çalışanları arasında özellikle onkoloji hastalarına bakım veren personel tükenmişlik açısından yüksek risk altındadır. ${ }^{11-15}$

Tükenmişlik ilk kez 1974 yılında Freudenberger tarafından, sağlık çalışanlarının işyerinde fiziksel ve psikolojik anlamda olumlu ya da olumsuz olarak yaşadığı durumların belirlenmesi ve olumsuz durumlara çözüm üretmek üzere ortaya konan bir kavramdır. ${ }^{16}$ Maslach ve Jackson tarafından sonraki yıllarda "kronik stres sonucunda iş hayatında ve insan ilişkilerinde bozulma, yorgunluk, umutsuzluk ve benlik saygısında azalmaya neden olan psikolojik bir sendrom" olarak bu kavram genişletilmiştir. ${ }^{17,18}$

Sağlık profesyonelleri üzerinde yapılan bazı araştırmalar tükenmişlik ile iş doyumu arasında pozitif ilişki olduğunu göstermektedir. ${ }^{19-21}$ iş doyumu "çalışanların işlerine bağlılıkları ve işyerinde ne kadar mutlu oldukları" ile ilgili bir kavramdır. ${ }^{22,23}$ Tıp ve teknolojideki değişimler, kurumların rekabetçi tutumları, hasta haklarının sık olarak gündeme gelmesi gibi nedenlerle hasta ve hasta yakınlarının sağlık çalışanlarından beklentileri, her geçen gün artmaktadır. Artan beklentilerin karşılanması ancak verimli çalışan sağlık profesyonelleri ile gerçekleşebileceğinden tükenmişlik ve iş doyumu konusu günümüzde ilgi çeken konulardır. ${ }^{24-26}$

Bizim yaptı̆̆ımız bu çalışma ile Adana'da onkoloji-hematoloji klinik ve polikiniklerinde görev yapan hemşirelerin tükenmişlik ve iş doyumu düzeylerinin belirlenmesi amaçlanmıştır.

\section{YÖNTEM}

\section{Araştırmanın Tipi}

Araştırmamız tanımlayıcı niteliktedir.

\section{Araştırmanın Yapıldığı Yer}

Araştırma 1 Haziran- 1 Temmuz 2014 tarihleri arasında Adana il merkezinde bulunan Çukurova Üniversitesi Tıp Fakültesi Balcalı Hastanesi, Adana Numune Eğitim ve Araştırma hastanesi, Başkent Üniversitesi Adana Uygulama ve Araştırma Hastanesi'nde onkoloji ve hematoloji birimlerinde görev yapan hemşirelerin katılımıyla yapılmıştır.

\section{Araştırmanın Evreni/ Örneklemi}

Araştırmada örneklem seçimine gidilmemiş Adana ilinde bulunan üç hastanenin onkoloji ve hematoloji birimlerinde görev yapan 75 hemşirenin tümü örnekleme alınmıştır. Araştırmanın yapıldığı tarihlerde görev 
yapan ve araştırmaya katılmayı gönüllü olarak kabul eden 72 hemşire araştırmaya dahil olmuştur, araştırmaya katılım oranı toplam \%96'dır.

\section{Veri toplama Araçları}

Araştırmanın verilerini toplamak için üç adet soru formu kullanılmıştır. İlk form Tanıtıcı Özellikleri Belirleme Formu, ikinci form Maslach Tükenmişlik Ölçeği, üçüncü form Minesota Iş̧ Tatmin Ölçeği'dir.

Tanıtıcı Özellikleri Belirleme Formu: Araştırmacılar tarafından literatürden elde edilen bilgilere göre hazırlanan bu form, katılımcıların yaş, medeni durum, çocuk sahibi olma durumları, mezun oldukları okul, çalıştıkları birim, bir günde bakım verilen hasta sayısı, çalışma süresi, son bir yıl içinde çalışılan bölümü değiştirme talebinin olup olmadığı gibi özelliklerini belirlemeye yönelik 14 sorudan oluşmaktadır.

Maslach Tükenmişlik Ölçeği: Maslach ve Jackson tarafından 1981 yılında geliştirilen Tükenmişlik Ölçeği 22 tükenmişlik ifadesi ve üç alt ölçekten oluşmaktadır. ${ }^{17}$ Alt ölçeklerden dokuz ifade duygusal tükenmeyi, beş ifade, duyarsızlaşmayı, sekiz ifade ise kişisel başarıyı ölçmektedir. Ölçeğin Türkçe'ye çevrilmesi, geçerlik ve güvenirlik çalışması Çapri ve Çam tarafından yapılmıştır. ${ }^{27,28}$ Duygusal tükenme ve duyarsızlaşma alt ölçeklerinden yüksek, kişisel başarı alt ölçeğinden düşük puan almak tükenmiş düzeyinin yüksek olduğunu göstermektedir (Tablo 1 ).

Tablo 1. Tükenmişlik Boyutlarının Orijinal Değerlendirilmesi

\begin{tabular}{llll}
\hline ALT BOYUTLAR & YÜKSEK & ORTA & DÜŞÜK \\
\hline Duygusal Tükenme & 18 ve Üzeri & $12-17$ & $0-11$ \\
Duyarsızlaşma & 10 ve Üzeri & $6-9$ & $0-5$ \\
Kişisel Başarı & $0-21$ & $22-25$ & 26 ve üzeri
\end{tabular}

Minnesota iş Tatmin Ölçeği: Minnesota iş̧ Doyumu Ölçeği Weiss ve arkadaşları tarafından 1967 yılında geliştirilmiştir. ${ }^{29}$ Ölçeğin Türkçe'ye çevirilmesi, geçerlik ve güvenirlik çalışması Baycan tarafından 1985 yılında yapılmıştır. ${ }^{30}$ Minnesota iş doyum ölçeği içsel ve dışsal doyum olmak üzere iki alt boyutu olan toplam 20 ifadeden oluşmaktadır. Ölçekten yüksek puan alınması iş doyumunun arttığını, düşük puan almak ise iş doyumunun düştüğünü göstermektedir.

\section{Araştırmanın Verilerinin Toplanması ve Değerlendirmesi}

Araştırmanın verileri araştırmacılar tarafından toplanmıştır.

Verilerin değerlendirmesi SPSS 16.0 paket programı ile yapılmıştır. İstatistiki verileri değerlendirmek için sayı-yüzde dağılımı, ortalama, spearman rho testi yöntemleri kullanıımıştır.

\section{Araştırmanın Etik Boyutu}

Araştırmaya başlamadan önce Çukurova Üniversitesi Tıp Fakültesi Etik Kurulu'ndan (14/02/2014-28) ve araştırmanın yapıldığı kurumlardan yazılı izinler alınmıştır. Katılımcılara araştırmanın amacı ve konu hakkında bilgi verildikten sonra bilgilerin yalnızca bilimsel amaçlarla kullanılacağı açıklanmıştır.

\section{BULGULAR}

Araştırmada hemşirelerin yaş ortalaması $31.2 \pm 8.4$ olup, \%56.9'unun evli, \%48.6'sının lisans mezunu, \%16.7'sinin ise onkoloji hemşireliği sertifikasına sahip oldukları belirlenmiştir. Hemşirelerin 28'inin (\%38.9) gündüz, 44'ünün (\%61.1) vardiya ya da nöbet şeklinde çalıştıkları belirlenmiştir (Tablo 2).

Örneklem Grubunda, Tükenmişlik Ölçeğinin, Duygusal Tükenme (DT) alt boyutunda hemşirelerin \%100'ünün

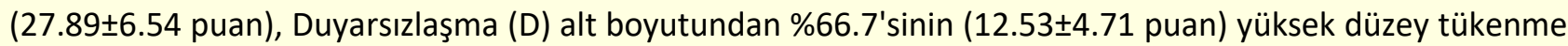
yaşadıkları, Kişisel Başarı (KB) alt boyutunda ise \%70.8'inin düşük düzey tükenmişlik yaşadıkları belirlenmiştir (Tablo 3). 
Tablo 2. Hemşirelerin Demografik Özellikleri

\begin{tabular}{|c|c|c|}
\hline Demografik veriler ( $N=72)$ & $\mathbf{n}$ & $\%$ \\
\hline \multicolumn{3}{|l|}{ Medeni Durum } \\
\hline Evli & 41 & 56,9 \\
\hline Bekar & 31 & 43,1 \\
\hline \multicolumn{3}{|l|}{ Çocuk Sayısı } \\
\hline Çocuğu yok & 30 & 41,6 \\
\hline Bir Çocuk & 14 & 19,4 \\
\hline iki Çocuk & 25 & 34,8 \\
\hline Üç Çocuk & 3 & 4,2 \\
\hline \multicolumn{3}{|l|}{ Öğrenim Düzeyi } \\
\hline Sağlık Meslek Lisesi & 17 & 23,6 \\
\hline Önlisans & 17 & 23,6 \\
\hline Lisans & 35 & 48,6 \\
\hline Lisansüstü & 3 & 4,2 \\
\hline \multicolumn{3}{|l|}{ Mesleği isteyerek seçme } \\
\hline Evet & 49 & 68 \\
\hline Hayır & 23 & 32 \\
\hline \multicolumn{3}{|l|}{ Çalıştıkları Hastane } \\
\hline Çukurova Üniversitesi Tıp Fakültesi Balcalı Hastanesi & 30 & 41,6 \\
\hline Adana Numune Eğitim ve Araştırma Hastanesi & 21 & 29,2 \\
\hline Başkent Üniveristesi adana Uygulama ve Araştrma Hastanesi & 21 & 29,2 \\
\hline \multicolumn{3}{|l|}{ Çalışma Şekli } \\
\hline Gündüz & 28 & 38,9 \\
\hline Vardiya/Nöbet & 44 & 61,1 \\
\hline \multicolumn{3}{|l|}{ Onkoloji Hemşireliği Sertifikası } \\
\hline Var & 12 & 16,7 \\
\hline Yok & 60 & 83,3 \\
\hline \multicolumn{3}{|l|}{ Son 1 yıl içinde yer değiştirme talebi } \\
\hline Var & 23 & 68 \\
\hline Yok & 49 & 32 \\
\hline Yaş Ortalaması (XIS.D) & \multicolumn{2}{|c|}{$31.2 \pm 8.4$} \\
\hline
\end{tabular}

Tablo 3. Hemşirelerin Tükenmişlik Ölçeğinden Aldıkları Puan Ortalamaları

\begin{tabular}{|c|c|c|c|c|c|}
\hline Alt Boyutlar & $\mathbf{N}$ & Minimum & Maximum & $\mathbf{x}$ & SD \\
\hline Duygusal tükenme & 72 & 12 & 40 & 27,89 & 6,545 \\
\hline Duyarsızlaşma & 72 & 5 & 25 & 12,53 & 4,717 \\
\hline Kişisel başarı & 72 & 17 & 37 & 27,99 & 4,271 \\
\hline \multicolumn{4}{|c|}{ TÜKENMIŞLIK ÖLÇEĞi iFADELERi } & $\mathbf{x}$ & SD \\
\hline \multicolumn{4}{|c|}{ 1. İşimden soğuduğumu hissediyorum. } & 3,44 & 1,019 \\
\hline \multicolumn{4}{|c|}{ 2. İş dönüşü kendimi ruhen tükenmiş hissediyorum. } & 3,92 & 1,031 \\
\hline \multicolumn{4}{|c|}{ 3. Sabah kalktığımda bir gün daha bu işi kaldıramayacağımı hissediyorum. } & 3,38 & 1,093 \\
\hline \multicolumn{4}{|c|}{ 4. İşim gereği karşılaştı̆̆ım insanların ne hissettiğini hemen anlarım. } & 3,90 & 0,772 \\
\hline \multicolumn{4}{|c|}{ 5.îşim gereği bazı kimselere sanki insan değillermiş gibi davrandığımı fark ediyorum. } & 1,82 & 1,226 \\
\hline \multicolumn{4}{|c|}{ 6. Bütün gün insanlarla uğraşmak benim için gerçekten çok yıpratıcı. } & 3,64 & 0,909 \\
\hline \multicolumn{4}{|c|}{ 7. İşim gereği karşılaştığım insanların sorunlarına en uygun çözüm yollarını bulurum. } & 3,83 & 0,732 \\
\hline \multicolumn{4}{|c|}{ 8. Yaptığım işten yıldığımı hissediyorum. } & 3,46 & 1,087 \\
\hline \multicolumn{4}{|c|}{ 9. Yaptığım iş sayesinde insanların yaşamına katkıda bulunduğuma inanıyorum. } & 3,99 & 0,896 \\
\hline \multicolumn{4}{|c|}{ 10. Bu işte çalışmaya başladığımdan beri insanlara karşı sertleştim. } & 2,76 & 1,316 \\
\hline \multicolumn{4}{|c|}{ 11. Bu işin beni giderek katılaştırmasından korkuyorum. } & 3,21 & 1,299 \\
\hline \multicolumn{4}{|c|}{ 12. Çok şeyler yapabilecek güçteyim. } & 3,35 & 0,995 \\
\hline
\end{tabular}


13. İşimin beni kısıtladığını düşünüyorum.

3,60

1,134

14. İşimde çok fazla çalıştığımı hissediyorum.

$3,94 \quad 1,099$

15. İşim gereği karşılaştığım insanlara ne olduğu umurumda değil.

$1,75 \quad 1,084$

16. Doğrudan doğruya insanlarla çalışmak bende çok fazla stres yaratıyor.

$3,22 \quad 1,189$

17. İşim gereği karşılaştığım insanlarla aramda rahat bir hava yaratırım.

$3,54 \quad 1,125$

18. Insanlarla yakın bir çalışmadan sonra kendimi canlanmış hissederim.

3,08

1,031

19. Bu işte birçok kayda değer başarı elde ettim.

20. Yolun sonuna geldiğimi hissediyorum.

2,74

1,321

21. İşimdeki duygusal sorunlara serinkanlııkla yaklaşırım.

3,38

1,041

22. İşim gereği karşılaştığım insanların bazı problemlerini sanki ben

İ̧ Doyum ölçeğinin içsel doyum(ID) puan ortalaması $36.19 \pm 9.88$, dışsal doyum(DD) puan ortalaması ise $21.64 \pm 6.26$ tür (Tablo 4). Hemşirelerin içsel iş doyumu maddelerinden "başkaları için bir şeyler yapabilme olanağına sahip olmam bakımından" işlerinden çok memnun oldukları ve en yüksek $(4.03 \pm 1.07)$ puanı aldıkları saptanmıştır. Dışsal iş doyumu maddelerinden ise "yaptığım iş ve karşılığında aldığım ücret bakımından" işlerinden hiç memnun olmadıkları ve en düşük $(1.81 \pm 1.04)$ puanı aldıkları saptanmıştır.

Tablo 4. İ̧ Doyum Ölçeğinden alınan Puan Ortalamaları

\begin{tabular}{|c|c|c|c|c|c|}
\hline Alt Boyut & $\mathbf{N}$ & Minimum & Maximum & $\mathbf{x}$ & SD \\
\hline İçsel doyum puanı & 72 & 12 & 52 & 36,19 & 9,880 \\
\hline Dışsal doyum puanı & 72 & 8 & 33 & 21,64 & 6,269 \\
\hline Genel iş doyum puanı & 72 & 20 & 85 & 57,83 & 15,236 \\
\hline \multicolumn{4}{|l|}{ IŞ TATMINI iFADELERI } & $\mathbf{X}$ & SD \\
\hline \multicolumn{4}{|c|}{ 1. Beni her zaman meşgul etmesi bakımından } & 2,21 & 1,150 \\
\hline \multicolumn{4}{|c|}{ 2. Tek başıma çalışma olanağımın olması bakımından } & 2,13 & 1,198 \\
\hline \multicolumn{4}{|c|}{ 3. Ara sıra değişik şeyler yapabilme şansımın olması bakımından } & 2,42 & 1,392 \\
\hline \multicolumn{4}{|c|}{ 4. Toplumda "saygın bir kişi” olma şansını bana vermesi bakımından } & 2,94 & 1,383 \\
\hline \multicolumn{4}{|c|}{ 5. Amirimin emrindeki kişileri idare tarzı açısından } & 2,99 & 1,439 \\
\hline \multicolumn{4}{|c|}{ 6. Amirimin karar vermedeki yeteneği bakımından } & 3,04 & 1,368 \\
\hline \multicolumn{4}{|c|}{ 7. Vicdanıma aykırı olmayan şeyleri yapabilme şansımın olması bakımından } & 3,15 & 1,411 \\
\hline \multicolumn{4}{|c|}{ 8. Bana sabit bir iş imkânı sağlaması bakımından } & 3,40 & 1,159 \\
\hline \multicolumn{4}{|c|}{ 9. Başkaları için bir şeyler yapabilme olanağına sahip olmam bakımından } & 4,03 & 1,074 \\
\hline \multicolumn{4}{|c|}{ 10. Kişilere ne yapacaklarını söyleme olanağına sahip olmam bakımından } & 3,56 & 1,137 \\
\hline \multicolumn{4}{|c|}{$\begin{array}{l}\text { 11. Kendi yeteneklerimi kullanarak bir şeyler yapabilme şansımın } \\
\text { olması açısından }\end{array}$} & 3,68 & 1,298 \\
\hline \multicolumn{4}{|c|}{ 12. İş ile ilgili kararların uygulamaya konması bakımından } & 3,01 & 1,144 \\
\hline \multicolumn{4}{|c|}{ 13. Yaptığım iş ve karşılığında aldığım ücret bakımından } & 1,81 & 1,043 \\
\hline \multicolumn{4}{|c|}{ 14. İş içinde terfi olanağımın olması açısından } & 2,17 & 1,113 \\
\hline \multicolumn{4}{|c|}{ 15. Kendi kararlarımı uygulama serbestliğini bana vermesi açısından } & 2,61 & 1,181 \\
\hline \multicolumn{4}{|c|}{$\begin{array}{l}16 \text { İşimi yaparken kendi yöntemlerimi kullanabilme şansını bana sağlaması } \\
\text { bakımından }\end{array}$} & 2,67 & 1,151 \\
\hline \multicolumn{4}{|c|}{ 17. Çalışma şartları bakımından } & 2,04 & 1,144 \\
\hline \multicolumn{4}{|c|}{ 18. Çalışma arkadaşlarımın birbirleriyle anlaşmaları açısından } & 3,75 & 1,184 \\
\hline \multicolumn{4}{|c|}{ 19. Yaptığım iş karşılığında takdir edilmem açısından } & 2,85 & 1,421 \\
\hline
\end{tabular}


Örneklem grubundaki hemşirelerin içsel doyum ve genel iş doyumu puanları nöbet veya vardiya şeklinde çalışanlarda düşük iken $(p<0,05)$, mesleğini isteyerek seçme/seçmeme ve medeni durumlarının iş doyumu puanlarını etkilemediği saptanmıştır ( $p>0.05)$.

Tablo 5'de görüldüğü gibi, Maslach tükenmişlik ölçeği duygusal tükenmişlik (DT) alt boyutu ile Minnesota iş doyum ölçeği içsel doyum (ID) alt boyutu arasında negatif yönde, orta düzeyde anlamlı bir ilişki söz konusudur ( $r=-0,569 ; p=0,000)$. Duyarsızlaşma (D) alt boyut puanları ile iD puanları arasında negatif yönde, zayıf düzeyde anlamlı bir ilişki söz konusudur $(r=-0,469 ; p=0,000)$. Kişisel başarı (KB) alt boyut puanları ile iD puanları arasında, pozitif yönde, orta düzeyde anlamlı bir ilişki söz konusudur $(r=0,444 ; p=0,000)$. DT puanları ile dışsal doyum (DD) puanları arasında negatif yönde, orta düzeyde anlamlı bir ilişki söz konusudur ( $r=-0,563 ; p=0.000)$.

Maslach tükenmişlik ölçeği $D$ alt boyut puanları ile DD puanları arasında negatif yönde, anlamlı bir ilişki söz konusudur $(r=-0,472 ; p=0.000)$. KB puanları ile DD puanları arasında pozitif yönde anlamlı bir ilişki söz konusudur $(r=0,404 ; p=0.000)$.

Maslach tükenmişlik ölçeği DT puanları ile Genel İş doyumu (GiD) puanları arasında negatif yönde orta düzeyde anlamlı bir ilişki söz konusudur $(r=-0,600 ; p=0.000)$. D puanları ile GiD puanları arasında negatif yönde orta düzeyde anlamlı bir ilişki söz konusudur $(r=-0,498 ; p=0.000)$. KB puanları ile GiD puanları arasında pozitif yönde anlamlı bir ilişki olduğu belirlenmiş̧tir $(r=0,454 ; p=0.000)$. D puanları ile DT puanları arasında pozitif yönde orta düzeyde anlamlı bir ilişki söz konusudur ( $r=0,579 ; p=0.000)$.

Maslach tükenmişlik ölçeği KB puanları ile DT puanları arasında anlamlı bir ilişki söz konusu değildir ( $r=-$ $0,225 ; p=0.057)$. KB puanları ile $D$ puanları arasında negatif yönde zayıf düzeyde anlamlı bir ilişki söz konusudur $(r=-0,346 ; p=0.003)$.

ID puanları ile DD puanları arasında pozitif yönde orta düzeyde anlamlı bir ilişki söz konusudur $(r=0,771$; $p=0.000$ ). ID ile GiD puanları arasında pozitif yönde çok yüksek düzeyde anlamlı bir ilişki söz konusudur $(r=0,996 p=0.000)$. DD boyutu ile GiD puanları arasında pozitif yönde çok yüksek düzeyde anlamlı bir ilişki söz konusudur. $(r=0,910 ; p=0.000)$

Tablo 5. Hemşirelerin, Minnesota Iş̧ Doyum Ölçeği Alt Boyut Puanları ile Maslach Tükenmişlik Ölçeği Alt Boyut Puanları Arasındaki ilişkileri

\begin{tabular}{|c|c|c|c|c|c|c|c|c|}
\hline & & $\begin{array}{l}\text { Tükenmişlik } \\
\text { Sendromu }\end{array}$ & $\begin{array}{l}\text { Genel İş } \\
\text { Doyumu }\end{array}$ & $\begin{array}{l}\text { İçsel } \\
\text { Doyum }\end{array}$ & $\begin{array}{l}\text { Dışsal } \\
\text { Doyum }\end{array}$ & $\begin{array}{l}\text { Duygusal } \\
\text { Tükenme }\end{array}$ & Duyarsızlaşma & $\begin{array}{l}\text { Kişisel } \\
\text { Başarı }\end{array}$ \\
\hline Tükenmişlik & $r$ & 1 &,$- 460^{* *}$ &,$- 429^{* *}$ &,$- 443^{* *}$ &, $874^{* *}$ & ,729** & ,106 \\
\hline Sendromu & $\mathbf{p}$ & & ,000 & ,000 & ,000 & ,000 & ,000 & ,374 \\
\hline Genel İş & $r$ & & 1 &, $966^{* *}$ & ,910** &,$- 600^{* *}$ &,$- 498^{* *}$ &, $454^{* *}$ \\
\hline Doyumu & $\mathbf{p}$ & & & ,000 & ,000 & ,000 &, 000 & ,000 \\
\hline \multirow[t]{2}{*}{ İçsel Doyum } & $r$ & & & 1 &, $771^{* *}$ &,$- 569^{* *}$ &,$- 469^{* *}$ &, $444^{* *}$ \\
\hline & $\mathbf{p}$ & & & & ,000 & ,000 & ,000 & ,000 \\
\hline \multirow[t]{2}{*}{ Dışsal Doyum } & $r$ & & & & 1 &,$- 563^{* *}$ &,$- 472^{* *}$ &, $404^{* *}$ \\
\hline & $\mathbf{p}$ & & & & &, 000 & ,000 &, 000 \\
\hline Duygusal & $r$ & & & & & 1 &, $579^{* *}$ &,- 225 \\
\hline Tükenme & $\mathbf{p}$ & & & & & &, 000 & ,057 \\
\hline \multirow[t]{2}{*}{ Duyarsızlaşma } & $r$ & & & & & & 1 &,$- 346^{* *}$ \\
\hline & $\mathbf{p}$ & & & & & & & ,003 \\
\hline \multirow[t]{2}{*}{ Kişisel Başarı } & $r$ & & & & & & & 1 \\
\hline & $\mathbf{p}$ & & & & & & & \\
\hline
\end{tabular}

** Correlation is significant at the 0.01 level (2-tailed).

\section{TARTIŞMA}

Araştırmamızın sonuçlarına göre onkoloji birimlerinde görev yapan hemşirelerin duygusal tükenme alt boyutunda ve duyarsızlaşma alt boyutunda yüksek düzey tükenmişlik yaşadıkları, kişisel başarısızlık alt boyutunda ise düşük düzey tükenmişlik yaşadıkları belirlenmiştir (Tablo 3). İş doyumu düzeyleri ise alt boyutlara göre hemşirelerin içsel doyum maddelerinden "başkaları için bir şeyler yapabilmenin" iş doyumunu arttırdığı görülmektedir. Bu sonuçlar onkoloji hemşirelerinin kişisel başarısızlık düzeylerinin 
düşük, duygusal tükenmişlik ve duyarsızlaşma düzeylerinin yüksek, iş tatmini düzeylerinin ise orta $(57,83 \pm 15,236)$ olduğunu göstermektedir. Katılımcılarımızın tükenmişlik ve iş doyumu bulguları arasında istatistiksel olarak anlamlı düzeyde bir ilişki olduğu tespit edilmiştir (Tablo 5). İçsel doyum ile kişisel başarı puanları arasında pozitif yönde, duygusal tükenme ve duyarsızlaşma arasında negatif yönde bir ilişki vardır. Genel iş doyumunun artması ile duygusal tükenme ve duyarsızlaşmanın da azaldığı saptanmıştır. Bu bulgularımız literatürle uyumludur. ${ }^{11,19,21,31,32}$ Delvaux ve Vaezi'nin yaptıkları araştırmalarda onkoloji hemşirelerinin farklı bakım ortamlarında çalışan meslektaşlarına göre hastaların acılarına uzun süreli şahitlik etmeleri nedeniyle tükenmişlik yaşadıkları ve düşük iş memnuniyetine sahip oldukları saptanmıştır. ${ }^{33,34}$ Kamışlı ve arkadaşlarının onkoloji birimlerinde çalışan hemşireler üzerinde yaptıkları araştırmada hemşirelerin yüksek düzeyde tükenmişlik yaşadıkları, iş stresi yönetiminde ve hastalara psikolojik bakım vermede yetersizlik hissettikleri ancak iş tatmini, klinik becerilerin ve yaşamın önceliklerine dair farkındalıklarının arttığı bildirilmektedir. ${ }^{14}$ Bu sonuçlar onkoloji hemşirelerinin hastaların fizyolojik, sosyal ve psikolojik gereksinimlerini karşılamak için özel bazı bilgi ve donanımlara gereksinimi olduğunu göstermektedir.

Araştırma sonuçlarımıza göre hemşirelerin tükenmişlik ölçeğinden en yüksek puan ortalamasını "yaptığım iş sayesinde insanların yaşamına katkıda bulunduğuma inanıyorum" ifadesinden almıştır. İş doyumu ölçeğinde ise "kendi yeteneklerimi kullanarak bir şeyler yapabilme şansımın olması açısından işimden memnunum" ve "başkaları için bir şeyler yapabilme olanağına sahip olmam bakımından işimden memnunum" ifadeleri en yüksek puan ortalamalarına sahiptir. Bu sonuçlara göre hemşirelerin iş doyumu sağlamaları özerk olmaları ve bağımsız hemşirelik rollerini yerine getirmeleri ile ilişkilidir. Hemşirelerin gün içinde onkoloji hastaları ve ailelerinin yaşadığı birçok olumsuzluklara şahit olmaları, vicdani duygularına göre davranmalarına neden olabilir. Bulgularımıza göre hemşireler "vicdanıma aykırı olmayan şeyleri yapabilme şansımın olması bakımından işimden memnunum" ifadesinden yüksek puan almıştır. Hemşirelik alanında yapılan bazı çalışmalar hemşirelerin özellikle etik açıdan zorluk içeren durumlarda hastalarını ve kendilerini korumak için vicdanlarına uygun davranma eğiliminde olduklarını bildirmektedir. ${ }^{33,34}$ Vicdana uygun davranmak hem kişisel bütünlüğün hem de mesleki değerlerin korunması için önemli bir faktördür. ${ }^{35,36}$ İsveç'te yapılan bazı araştırmaların sonuçlarına göre, işyerinde vicdana uygun olmayan tutum ve davranışlarda bulunmak ya da şahit olmak hemşirelerde tükenmişliği arttıran bir faktördür. ${ }^{37-39}$ Kadıoğlu ve Öner Yalçın'ın ülkemizde hemşire ve hemşirelik öğrencileri üzerinde yaptıkları iki ayrı araştırmada da hemşirelik uygulamaları sırasında "vicdanın sesi"nin dinlenmesi gerektiği görüşü benimsenmiştir. ${ }^{40,41}$ Bizim araştırmamızda hemşireler, vicdanlarına uygun hasta bakımı yaptıklarını ve iş doyumuna eriştiklerini belirtmelerine rağmen, yine yüksek düzeyde tükenmişlik yaşamakta ve yaptıkları işe karşı duyarsızlaşmaktadır. Bu durum, tükenmişliğe gidişin her zaman "vicdana uygun davranmamak" üzerinden olmadığını göstermektedir. Katılımcılarımız vicdanlarına uygun davranabilmekte; ancak işyerinde bir yandan fiziksel yorgunluk, öte yandan yaptıklarının takdir görmemesi ve maddi karşılığının olmaması, terfi olanağının az olması gibi konular nedeniyle tükenmişliğe sürüklenmekten kurtulamamaktadır.

Bulgularımıza göre onkoloji hemşireleri yaptıkları iş karşılığında aldıkları ücretten memnun olmadıklarını ve çalışma şartlarının ağır olduğunu belirtmiştir. Hemşirelerin genel iş doyumu puanları nöbet veya vardiya şeklinde çalışanlarda gündüz çalışanlara göre daha düşüktür $(p<0,05)$. Barrett ve arkadaşlarının yaptığı araştırmaya göre de onkoloji hemşirelerinin \%40’ı aldığı ücretten memnun olmadığını belirtmiş, iş doyumu bakımından bizim araştırmamızla benzer sonuçlar elde edilmiştir. ${ }^{21}$ Yaptığı işte hem maddi hem de manevi açıdan doyuma ulaşamayan kişilerin iş verimleri düşük olmaktadır. ${ }^{42}$ Çalışanların tükenmişlik düzeylerini düşüren bir diğer faktörde iş motivasyonudur. ${ }^{43,44}$ Kanada'da yapılan bir araştırmanın sonuçlarına göre onkoloji hemşirelerinin yöneticilerle olumlu ilişkiler kurmaları, yeterli ücret ve yeterli personele sahip olmaları, hasta ile ilgili kararlara katılmaları iş motivasyonunu ve iş doyumunu arttırmaktadır. ${ }^{45}$ Onkoloji hemşirelerinin tükenmişlik düzeylerini azaltmak, iş doyumlarını arttırmak için yeterli ücret almanın yanında, hastalarla dengeli empati kurmaya, gerçek ve ulaşılabilir bakım hedefleri koymaya ve yöneticilerin güçlü desteğini almaya ihtiyaçları vardır. ${ }^{46}$ Ülkemizde Onkoloji Hemşireliği Derneği bu alanda bilgili hemşirelerin yetiştirilmesi için "onkoloji hemşireliği" sertifika programları düzenlemektedir. Ancak hasta sayısına göre onkolojide özel eğitim almış, sertifikalı hemşirelerin sayısı azdır. Diğer bir sorun ise, onkolojinin özellikli alan 
olarak kabul görmüş olmaması nedeniyle onkoloji hemşirelerinin maddi anlamda diğer dahiliye birimleriyle eşdeğer ücret almasıdır. ${ }^{47}$

Tükenmişlik alt boyutları, duygusal tükenme, duyarsızlaşma ve kişisel başarı ile içsel doyum arasında istatistiksel olarak anlamlı düzeyde bir ilişki bulunmuştur. İçsel doyum ile kişisel başarı arasında pozitif yönde ilişki bulunmuştur. İçsel doyumun artması ile duygusal tükenmenin ve duyarsızlaşmanın azaldığı saptanmıştır. Tükenmişlik alt boyutu, duygusal tükenme ve duyarsızlaşma ile dışsal doyum arasında negatif yönde anlamlı bir ilişki, kişisel başarı ile dışsal doyum arasında pozitif yönde anlamlı bir ilişki bulunmuştur. Dışsal doyumun artması ile duygusal tükenmenin ve duyarsızlaşmanın azaldığı, kişisel başarının arttığını söyleyebiliriz. Genel İş doyumun artması ile duygusal tükenmenin ve duyarsızlaşmanın azaldığı, kişisel başarının arttığı saptanmıştır. Tükenmişlik alt boyutlarının birbirleriyle anlamlı düzeyde ilişkili olduğu bulunmuştur. Duygusal tükenme ve kişisel başarı ile duyarsızlaşma arasında anlamlı bir ilişki saptanmıştır. Duygusal tükenmenin artması duyarsızlaşmayı da arttırmaktadır. Duygusal tükenme ve duyarsızlaşmanın azalması kişisel başarıyı arttırmaktadır. İş doyum alt boyutlarının birbirleriyle anlamlı düzeyde ilişkili olduğu bulunmuştur. İçsel doyum ile dışsal doyum arasında orta, genel iş doyumu ile içsel doyum ve dışsal doyum arasında yüksek düzeyde bir ilişki bulunmuştur. İçsel doyum artması ile dışsal ve genel iş doyumun arttığı saptanmıştır (Tablo 5). Bu sonuçlara göre, araştırma yapılan hastanelerde çalışan onkoloji hemşirelerinin iş doyumu ile tükenmişlik düzeyleri arasında negatif yönlü doğrusal bir ilişki olduğu söylenebilir. Bu bulgularımı literatürle uyumludur. ${ }^{21,31,32}$

Sonuç olarak, araştırma sonuçlarımıza göre katılımcı hemşireler yüksek düzeyde tükenme yaşamaktadır. Ancak hemşireler hastalarına yardım etmek için gösterdikleri çaba sayesinde kişisel başarı duygusu ve içsel iş tatminine de sahiptir. Onkoloji hemşirelerinin iş tatmini şüphesiz ki hasta bakımına sağlayacağı katkılar nedeniyle önemlidir. Onkoloji hemşirelerinin diğer birimlerde çalışanlara göre yaşadıkları özel zorluklar için ücretlerinde yapılacak iyileştirme, yönetimsel olarak başarılarının ödüllendirilmesi, onkoloji birimlerinde sık rastlanan sorunlarla nasıl baş edecekleriyle ilgili eğitim almaları iş doyumunu arttırarak tükenmişlik düzeyini azaltabilir.

\section{Bítgi}

Bu araştırma Çukurova Üniversitesi Bilimsel Araştırma Projeleri tarafından TSA-2014-1944 nolu proje olarak desteklenmiştir.

Bu araştırma 15-19 Ekim 2014 tarihinde Belek-Antalya'da düzenlenen 16.Ulusal iç Hastalıkları Kongresinde poster bildiri olarak sunulmuştur. Herhangi bir çıkar çatışması bulunmamaktadır.

\section{KAYNAKLAR}

1. Esther Kim JE, et al. A review of the prevalence and impact of multiple symptoms in oncology patients. Journal of Pain and Symptom Management 2009;37(4):715-736.

2. Kamal $\mathrm{AH}$, et al. Care needs of patients with cancer living in the community. Journal of Oncology Practice 2011;7(6):382-8.

3. TC Resmi Gazete. Hemşirelik Yönetmeliğinde Değişiklik Yapılmasına Dair Yönetmelik. 19 Nisan 2011, Sayı: 27910. Başbakanlık Basımevi. Ankara.

4. Balbay ÖA, ve ark. Burnout status of health care personnel working in oncology and their coping methods. HealthMED 2011;5(4):730-740.

5. Callaghan P, Tak-Ying SA, Wyatt PA. Factors related to stress and coping among chinese nurses in Hong Kong. Journal of Advanced Nursing 2000;31(6):1518-1527.

6. Lee J A. What is research for? The Lancet Oncology 2002;3(8):516.

7. Köşgeroğlu N, ve ark. Mesleki maruziyet nedeniyle hemşirelerde sitotoksik ılaçlarin kisa dönem yan etkilerinin görülme sıklığı ve hemoglobin, lökosit düzeylerinin belirlenmesi. Cumhuriyet Üniversitesi Hemşirelik Yüksekokulu Dergisi 2008;12(3);27-35.

8. Pınar R. Hemşirelerin kemoterapi hazırlama ve uygulama sırasında çevreyi kendilerini ve hastaları korumaya yönelik tutumları. Atatürk Üniversitesi Hemşirelik Yüksekokulu Dergisi 2003; 1:45-54.

9. Tuna R, Baykal Ü. Onkoloji hemşirelerinde iş stresi ve etkileyen faktörler. Florence Nightingale Hemşirelik Dergisi 2013;21(2): 92-100. 
10. Baykal Ü, Seren S, Sökmen S. A description of oncology nurses' working conditions in Turkey. European Journal of Oncology Nursing 2009;13(5):368-75.

11. Alacalıoğlu A, ve ark. Burnout in nurses and physicians working at an oncology department. Psychooncology 2009;18(5):543548.

12. İş̧en P. Onkologların çatışma eğilimlerinin, empatik becerilerinin, iş doyumlarının ve stresle başa çıkma tarzlarının incelenmesi. Yüksek Lisans Tezi. İstanbul: İstanbul Üniversitesi Sağlık Bilimleri Enstitüsü, 2006.

13. Radziewicz RM. Self-care for the caregiver. Nursing Clinics of North America 2001;36(4):855-69.

14. Kamışlı S, ve ark. Cancer patients and oncology nursing: Perspectives of oncology nurses in Turkey. The Nigerian Journal of Clinical Practice 2017;20(9):1065-1073

15. Papadatou D, Monos D, Anagnostopoulos F. Factors contributing to the development of burnout in oncology nursing. Psychology and Psychotherapy 1994;67(2):187-199.

16. Freudenberger Herbert J. Staff burn-out, Journal Social 1974:30(1):159-165.

17. Maslach C, Jackson SE. The measurement of experienced burnout. Journal of Organizational Behavior 1981;2(2):99-113.

18. Maslac C, Goldberg J. Prevention of burnout: new perspectives. Applied and Preventive Psychology 1998;7:63-74.

19. Toh SG, Ang E, Devi MK. Systematic review on the relationship between the nursing shortage and job satisfaction, stress and burnout levels among nurses in oncology/haematology settings. International Journal of Evidance-Based Healthcare 2012;10(2):126-41.

20. Zareifar S, et al. Job satisfaction and stress levels of nurses working in oncology wards; a multicenter study. Galen Medical Journal 2017;6(2):128-35.

21. Barrett LR, Yates P. Oncology/haematology nurses: a study of job satisfaction, burnout, and intention to leave the specialty. Australian Health Review 2002;25(3):109-121.

22. Mrayyan MT. Nurse job satisfaction and retention: comparing public to private hospitals in Jordan. Journal of Nursing Management 2005;13(1):40-50.

23. Odom RY, Boxx RW, Dunn MG. Organizational cultures, commitment, satisfaction, and cohesion. Public Productivity \& Management Review 1990;14(2):157-169.

24. Weber A, Jaekel-Reinhard A. Burnout syndrome: a disease of modern societies? Occupational Medicine 2000;50(7):512-517.

25. Arıkan F, ve ark. Job satisfaction and nursing. Nursing Forum 2006;1(1):4-10.

26. AbuAIRub RF. Job stress, job performance, and social support among hospital nurses. Journal of Nursing Scholarship 2004;36(1):73-8.

27. Çapri B. Tükenmişlik Ölçeğinin Türkçe Uyarlaması: Geçerlilik ve Güvenilirlik Çalışması, Mersin Üniversitesi Eğitim Fakültesi Dergisi 2006;2(1):62-77.

28. Çam O. Tükenmişlik envanterinin geçerlilik ve güvenilirliğin araştırılması. VII. Ulusal Psikoloji Kongresi Bilimsel Çalışmaları. 1992; 22-25 Eylül, Ankara, Hacettepe Üniversitesi.

29. Weiss DJ, et al. Manual for the Minnesota Satisfaction Questionnaire. The University of Minnesota Press. Minneapolis. 1967.

30. Baycan A. An analysis of several aspects of job satisfaction between different occupational groups. Boğaziçi Üniversitesi Yayınlanmamış Yüksek Lisans Tezi. 1985. İstanbul.

31. Tunçel Yi, ve ark. Onkoloji hastanesi yoğun bakım ünitesinde hemşirelerin tükenmişlik sendromu. Türk Yoğun Bakım Derneği Dergisi 2014;12:57-62.

32. Güveli H, ve ark. Oncology staff: burnout, job satisfaction and coping with stress. Psysico-Onkology 2015;24(8):926-931.

33. Delvaux $\mathrm{N}$, et al. Effects of 105 hours psychological training program on attitudes, communication skills and occupational stress in oncology: a randomised study. British Journal of Cancer 2004;90(1):106-14

34. Vaezi M, et al. Emotional, social and occupational adjustment among oncology nurses. International Journal of Hematology Oncology and Stem Cell Research 2016;10(4):195-199.

35. Torjuul K, Elstad I, Sørlie V. Compassıon and responsıbılıty in surgıcal care. Nursing Ethics 2007; 4(4):522-534.

36. Jensen A, Lidell $E$. The influence of conscience in nursing. Nursing Ethics 2009;16(1):31-42.

37. Juthberg $\mathrm{C}$, et al. Stress of conscience and perceptions of conscience in relation toburnout among care-providers in older people. Journal of Clinical Nursing 2008;17(14):1897-1906.

38. Glasberg AL, Eriksson S, Norberg A. Burnout and 'stress of conscience' among healthcare personnel. Journal of Advenced Nursing 2007;57(4):392-403. 
39. Åhlin J, et al. A comparison of assessments and relationships of stress of conscience, perceptions of conscience, burnout and social support between healthcare personnel working at two different organizations for care of older people. Scandinavian Journal of Caring Sciences 2015;29(2):277-287.

40. Kadıoğlu FG, Öner Yalçın S. Nurses' and physicians' views on conscience in Turkey. Revista Romana de Bioetica 2014;12(3):1931.

41. Kadıoğlu FG, Öner Yalçın S. Kadıoğlu S. Professional differences between dental and nursing students' views on conscience. Journal of Education and Ethics in Dentistry 2016;6(1):8-13.

42. Zeynel E, Çarıkçı ïH. Mesleki motivasyonun, iş tatmini ve örgütsel bağlılık üzerine etkisi: akademisyenler üzerine görgül bir araştırma. Süleyman Demirel Üniversitesi İktisadi ve İdari Bilimler Fakültesi Dergisi 2015;20(3):217-248.

43. Sat S. Örgütsel ve bireysel özellikler açısından iş doyumu ile tükenmişlik düzeyi arasındaki ilişki: alanya'da banka çalışanları üzerinde bir inceleme. Çukurova Üniversitesi Sosyal Bilimler Enstitüsü İşletme Anabilim Dalı. Yüksek Lisans Tezi. 2011. Adana.

44. Jasperse M, Herst P, Dungey G. Evaluating stress, burnout and job satisfaction in New Zealand radiation oncology departments. Eurupion Journal of Cancer Care 2014;23(1):82-88.

45. Cummıngs GG, et al. The relationship between nursing leadership and nurses' job satisfaction in canadian oncology work environments. Journal Of Nursing Management 2008;16(5):508-518.

46. Güner P. Tükenmeden Çalışmak: Mümkün mü? 5. Türk Tıbbi Onkoloji Kongresi, 19-23 Mart 2014, Antalya.

47. Kaya HP, Kanser tedavisinde onkoloji hemşireliğinin yeri ve geleceği. 2013. Erişim Tarihi: 04.4.2019 (update 30 Ağustos 2013; cited 9 Eylül 2013) Erişim Adresi: https://www.medikalakademi.com.tr/kanser-tedavisi-onkoloji-hemsireligi-egitim/ 